Ambiente \& Água - An Interdisciplinary Journal of Applied Science
ISSN 1980-993X - doi:10.4136/1980-993X
www.ambi-agua.net
E-mail: ambi-agua@agro.unitau.br

\title{
Poluição atmosférica veicular e o direito tributário ambiental no Brasil: proposta de reestruturação tributária para o desenvolvimento sustentável
}

\author{
doi: 10.4136/ambi-agua.1373
}

Received: 16 Aug. 2013; Accepted: 02 Dec. 2013

\author{
Pedro Monteiro Machado de Almeida Penna*; \\ Luiz Fernando Costa Nascimento; Cyro de Barros Rezende Filho (in memoriam) \\ Universidade de Taubaté (UNITAU), SP \\ Pós-graduação em Ciências Ambientais da Universidade de Taubaté \\ *Autor correspondente: e-mail: pedroap@ig.com.br, \\ luiz.nascimento@unitau.br,ambiente@unitau.br
}

\section{RESUMO}

O presente trabalho tem por objetivo apresentar a reestruturação dos tributos no setor automotivo no Brasil, visando ao desenvolvimento sustentável. Os veículos automotores, de passeio, caminhão ou ônibus, emitem gases que contribuem para o aquecimento global e que causam problemas à saúde humana. No Brasil existem políticas públicas para redução da emissão de poluentes atmosféricos por veículos, no entanto nenhuma delas é eficiente para punir o proprietário de veículo poluidor. Além disso, não é realizada a compensação dos danos ambientais. O Direito Tributário, com auxílio do Princípio Constitucional do Poluidor Pagador, é um eficiente instrumento de intervenção na Economia pelo Estado. Realizou-se no trabalho o comparativo ambiental e econômico de combustíveis e meios de transporte individual e coletivo. Estimaram-se os benefícios ambientais da reciclagem de veículos com mais de 10 anos de uso, considerando os poluentes na fabricação de um veículo novo. Por fim, foi proposta a unificação de tributos no Brasil, na aquisição de veículos, a extinção do IPVA e do ICMS e PIS/COFINS sobre combustíveis, concentrando-se a cobrança de tributos sobre combustíveis na CIDE-combustíveis, sem afetar a arrecadação do governo brasileiro, bem como vinculando parte das receitas desse tributo sobre combustível para a finalidade da reparação dos danos ambientais. Foram apresentadas sugestões para aprimoramento de políticas públicas que combatem a emissão de poluentes atmosféricas por veículos.

Palavras-chave: veículos automotores, combustíveis, sustentabilidade.

\section{Vehicular air pollution and environmental tax law in Brazil: proposed tax restructuring for sustainable development}

\begin{abstract}
This work presents a restructuring of taxes in the automotive sector in Brazil in order to foster sustainable development. Personal vehicles, trucks or buses emit gases that contribute to global warming and cause human health problems. There are policies in Brazil to reduce the emission of air pollutants from vehicles; however, these neither punish the polluter nor
\end{abstract}


provide for damage compensation. The Tax Law, with the Constitutional Polluter Pays Principle, is an efficient instrument for State intervention in the economy. The work compared environmental and economic views regarding fuel and both personal and public vehicles. We estimated the environmental benefits of recycling vehicles in use more than 10 years, taking into consideration pollution engendered in the manufacture of a new vehicle. Finally, we propose to unify vehicular taxation when the vehicle is acquired, by ending the ICMS and PIS / COFINS taxes on fuels and instead taxing CIDE-fuels, without reducing overall collection by the Brazilian government. The ensuing revenue would be used for repairing environmental damages. We have also made suggestions for the improvement of public policies to control emissions of atmospheric pollutants.

Keywords: vehicles, fuels, sustainability.

\section{INTRODUÇÃO}

Os veículos automotores emitem diversos gases poluentes. Esses gases incluem-se dentre aqueles do efeito estufa, que estão contribuindo para o aquecimento global e que causam problemas à saúde humana. No Brasil, o transporte rodoviário é responsável por 82,35\% de emissões de gases de efeito estufa (GEE) no setor de transportes.

Existem políticas públicas de redução da poluição atmosférica veicular: o PROCONVE, a Inspeção Veicular, Etiquetagem de veículos do INMETRO, Nota Verde do IBAMA, Política Estadual Paulista de Mudanças Climáticas, Fundo Nacional de Mudanças Climáticas, Reciclagem de Caminhões em São Paulo e Incentivos ao uso da bicicleta. As atuais políticas públicas brasileiras não são eficientes na prevenção e punição financeira dos agentes causadores de poluição atmosférica veicular e no incentivo a novas tecnologias mitigadoras de poluentes atmosféricos e recuperação de danos ambientais.

Como no Brasil existem muitos tributos sobre aquisição e uso de veículos e aquisição de combustíveis, a relevância do tema deste trabalho é a utilização do Direito Tributário como eficiente ferramenta social de proteção ao meio ambiente.

O objetivo central é a propositura de uma revisão da estrutura tributária sobre a produção e uso de veículos automotores, de passeio, caminhões e ônibus, e sobre a aquisição de combustíveis pelos usuários desses veículos. Propõe-se também que a receita financeira dos tributos seja vinculada a atividade governamental de fiscalização e reparação do meio ambiente degradado.

Como objetivo secundário foi realizado comparativo ambiental e financeiro entre os principais combustíveis utilizados por veículos em transporte individual (etanol, gasolina, diesel, GNV e eletricidade) e em transporte coletivo, por ônibus e metrô (diesel e eletricidade). Outro objetivo secundário foi a avaliação dos benefícios ambientais na reciclagem de veículos e na renovação da frota, comparando-se a emissão de gases poluentes da fabricação de veículo novo com a emissão de um veículo de 10 anos de fabricação, considerando a emissão de GEE na fabricação de um veículo novo.

Os resultados foram baseados em diversos documentos, principalmente mediante emissões atmosféricas estipuladas pelo Programa Brasileiro GHG Protocol, instituída pela Fundação Getúlio Vargas. A arrecadação total tributária do setor automotiva é elevada. Foi mantida integralmente, mas aprimorada na unificação de tributos e na vinculação de parte das receitas para a reparação ambiental das emissões atmosféricas. Dessa forma, em grande parte os objetivos foram alcançados. 


\section{REVISÃO DA LITERATURA}

\subsection{Poluição Atmosférica Veicular}

\subsection{1. Ética Ambiental. Sustentabilidade e Veículos}

A preocupação com o meio ambiente é recente na história do ser humano. Em 1972, na Conferência da ONU em Estocolmo, conhecida como a Declaração de Estocolmo, apresentou-se a preocupação de preservação ambiental. Em 1992 foi editada a Declaração do Rio de Janeiro, que estabeleceu princípios de desenvolvimento sustentável, princípio da precaução, educação ambiental, capacitação técnica e científica, poluidor pagador e internalização de custos ambientais. Em 1997 foi celebrado o Protocolo de Quioto, que estabeleceu metas de redução de 5\% das emissões de GEE, tendo como base o ano de 1990, para 37 países (Brasil, 2011).

A Conferência Rio + 20, realizada em 2012, no Rio de Janeiro, apresentou um documento final com muitos princípios e reafirmação de tratados anteriores. O mais significativo foi a inclusão do combate à pobreza como condição para o desenvolvimento sustentável. Não foi estabelecida nenhuma regra obrigatória quanto ao clima (ONU, 2012).

No século 21, a ética empresarial da sustentabilidade consolidou-se com 3 dimensões, com base no denominado "Triple Botton Line": econômica, relacionada ao lucro; social, relacionada à educação, cultura, lazer e justiça; e, a sustentabilidade ecológica (Vellani e Ribeiro, 2006, p. 3). Segundo a OICA (Organização Mundial de Fabricantes de Veículos) a sustentabilidade deve ser alcançada por meio do "integrated approach", representado pelos seguintes fatores: tecnologia veicular, combustíveis alternativos, direção ecológica, infraestrutura de transporte, tributos ambientais sobre emissão de dióxido de carbono (OICA, 2011).

\subsubsection{Veículos Automotores no Brasil e no Mundo}

Considerando o ano de 2010, os Estados Unidos têm a maior frota de veículos do mundo, 239 milhões de veículos, com a proporção de 1,30 habitantes por veículo. A China tem a $2^{\mathrm{a}}$ maior frota, com 78 milhões de veículos, com a proporção de 17,1 habitantes por veículo. $\mathrm{O}$ Brasil é a nona maior frota do mundo, com 32 milhões de veículos e proporção de 6 habitantes por veículo (SINDIPEÇAS, 2012).

No Brasil o setor automotivo, no ano de 2011, considerando as montadoras e autopeças, oferece 375 mil empregos, com um faturamento de R $\$ 105$ bilhões ano, com participação de $18,20 \%$ na indústria brasileira. Em tributos, considerando fabricação, uso e combustíveis, são R\$ 205 bilhões arrecadados (ANFAVEA, 2012a ; SINDIPEÇAS, 2012).

Com o aumento de renda e aumento de população economicamente ativa, se o Brasil chegar aos níveis econômicos de países desenvolvidos, a frota de veículos poderá quadruplicar. Considerando o crescimento populacional gradual e o crescimento de veículos em 7\% ao ano, teríamos 2 pessoas por veículo no Brasil, no ano de 2030, com uma frota de 123 milhões de veículos.

\subsubsection{Catalisadores, Combustíveis e Novas Tecnologias}

O catalisador automotivo tem por função a redução de gases poluentes. Os catalisadores tornaram-se obrigatórios no Brasil a partir de 1992. O catalisador denominado de três vias controla a emissão de monóxido de carbono, hidrocarbonetos e óxidos de nitrogênio (Garcia, 2003). Os catalisadores com tempo de uso perdem sua eficiência em média em 3 vezes (MELO et al., 2009).

O Brasil produz e consome combustíveis fósseis para o transporte (diesel, gasolina e GNV) e os biocombustíveis (etanol e óleos) são utilizados isoladamente ou na mistura com 
combustíveis fósseis. O diesel é utilizado principalmente para transporte de carga e de passageiros, e os veículos leves utilizam principalmente etanol, gasolina e GNV.

O etanol pode ser dividido em etanol hidratado (E100), misturado com água $(0,4 \%$ a 4,9\%), conforme a Resolução ANP 23/2010, destinado à venda diretamente ao consumidor, e etanol anidro, destinado a mistura com a gasolina A (pura), transformando-se na gasolina C, na proporção de $20 \%$ (BRASIL, 2010). A partir de 2010, tornou-se obrigatória a mistura de $5 \%$ de biodiesel na composição do diesel (D5), conforme Resolução 6/2009, do CNPE (Brasil, 2009b).

O diesel passou por redução de enxofre de 500 ppm para 10 ppm, em 2013, nas regiões metropolitanas (BRASIL, 2011). Os caminhões a Diesel, fabricados a partir de 2012, na fase P7 do PROCONVE, emitem menos poluente, com redução de $60 \%$ da emissão do NOx e 80\% do MP, em relação à fase P5 (ANFAVEA, 2012b).

As vantagens dos veículos elétricos são as baixas emissões de poluentes, e as desvantagens são a baixa autonomia, em média de 50 a $200 \mathrm{~km}$ (um veículo convencional tem autonomia de aproximadamente $500 \mathrm{~km}$ ), o elevado preço das baterias, horas de abastecimento e reduzido número de postos de abastecimento (SMITH, 2010). Os veículos movidos a eletricidade emitem GEE indiretamente, em razão da emissão de GEE na geração da energia elétrica (BRASIL, 2012b).

As tecnologias automotivas podem reduzir a poluição veicular e o consumo de combustível. A perda de energia em um veículo inicia-se na combustão, quando se perde cerca de $2 / 3$ de energia química do combustível. É possível reduzir em $30 \%$ o consumo de combustíveis e a emissão de poluentes, com veículos híbridos e reduções de $10 \%$ a $20 \%$ com aprimoramento em motor, injeção direta, redução de massa do veículo e partida integrada (SMITH, 2010).

\subsubsection{Atmosfera e padrões de qualidade do ar}

A atmosfera é um sistema termodinâmico que tem como principal fonte de calor a radiação solar, mantendo o equilíbrio térmico do Planeta, num ambiente ideal (Vianello, 1991).

A poluição atmosférica pode ser conceituada pela presença de contaminantes em quantidade e duração que sejam prejudiciais ao ser humano, fauna e flora, de acordo com a Resolução CONAMA 03/90 (Brasil, 1990). O comparativo de padrões de qualificação do AR são bem inferiores para o CONAMA; por exemplo, o padrão de qualidade para Material Particulado da OMS é 3 vezes inferior ao padrão do CONAMA.

De 2008 a 2011, em São José dos Campos foram ultrapassados os limites de qualidade do ar para Material Particulado e, mais gravemente, para Ozônio, que teve 37 dias com condição inadequada/má. Nos mesmos anos, no município de São Paulo, na região de Congonhas, e para o Ozônio na região do Ibirapuera, foram ultrapassados os limites de qualidade do AR para Materiais Particulados e, mais gravemente, para Dióxido de Nitrogênio e Ozônio (CETESB, 2012c).

\subsubsection{Poluição Veicular Atmosférica e Consequências à Saúde Humana}

Durante o processo de queima de combustíveis ocorre liberação de $\mathrm{CO}_{2}$ (Dióxido de Carbono). Outra parte menor de carbono é liberada na forma de CO (Monóxido de Carbono), $\mathrm{CH}_{4}$ (Metano) e VOC (Compostos Orgânicos Voláteis), que se oxidam na atmosfera, formando o $\mathrm{CO}_{2}$. (Dióxido de Carbono) e que, como efeito secundário, geram os poluentes $\mathrm{N}_{2} \mathrm{O}$ (Óxido Nitroso) e NOx (Óxidos de Nitrogênio) (CESTEB, 2011). Os veículos automotores emitem também HC (hidrocarbonetos totais), RCHO (aldeídos), Sox (óxidos de enxofre), MP (partículas inaláveis) e hidrocarbonetos não queimados (CETESB, 2010). 
O dióxido de carbono tem por origem o processo de combustão. Não é um gás tóxico, mas seu excesso causa o aquecimento global. O monóxido de carbono é um gás tóxico, causa redução de oxigenação, dores de cabeça, dificuldade visual, dores abdominais e cansaço, dentre outros problemas (Olmo, 2010). O aumento de $1 \mathrm{ppm}$ de $\mathrm{CO}$ acarretou o aumento de internações de idosos em 2,4\% para doenças respiratórias, 4,9\% para DPOC e 3,9\% para pneumonia (Gouveia et al., 2006). O metano, que tem potencial de aquecimento global, é 26 vezes mais em relação ao $\mathrm{CO}_{2}$ (Observatório do Clima, 2012). O dióxido de nitrogênio, que juntamente com os hidrocarbonetos emitidos pelos veículos, forma os gases precursores dos nevoeiros fotoquímicos, ou smog, é tóxico e irritativo (Olmo, 2010). Os aldeídos são provenientes especialmente do álcool, e há pequena literatura médica sobre suas consequências ao ser humano (Saldiva et al., 2011). O dióxido de enxofre, um gás irritante, forma as chuvas ácidas, que causa danos à vegetação e à colheita (CETESB, 2011). O material particulado causa alteração da função ciliar de remoção, aumento das infecções respiratórias, decréscimo da função pulmonar, aumento de hospitalizações (Olmo, 2010), aumenta as chances de $12 \%$ de internação por acidente vasculoencefálico (Nascimento e Moreira, 2006), está associado ao aumento de 2,4\% de internações de crianças menores de 5 anos devido a doenças respiratórias, 2,1\% por pneumonia e 4,6\% por asma (Gouveia et al., 2006), e agrava a apneia do sono (Zanobetti et al., 2010). O ozônio, no nível do solo, provoca problemas respiratórios, como o aumento de reatividade das vias aéreas e inflamação pulmonar (Olmo, 2010), e pode causar câncer de pele (Pavão e Nomura, 2009).

\subsubsection{Aquecimento Global}

O efeito estufa é fundamental à vida no planeta. Sem ele, a temperatura da Terra ficaria próxima a $-20^{\circ} \mathrm{C}$ Segundo alguns estudos, os níveis de $\mathrm{CO}_{2}$ cresceram $36 \%$ em relação aos níveis encontrados no século XVIII, antes da Revolução Industrial, principalmente em razão do uso de combustíveis fósseis (National Geografic, 2012). O metano $\left(\mathrm{CH}_{4}\right)$ tem a capacidade de absorver calor 26 vezes mais em relação ao $\mathrm{CO}_{2}$, e seu potencial de aquecimento global em 20 anos é de 72 vezes mais em relação ao $\mathrm{CO}_{2}$. O óxido nitroso $\left(\mathrm{N}_{2} \mathrm{O}\right)$ tem a capacidade de absorver calor 216 vezes mais em relação ao $\mathrm{CO}_{2}$, e seu potencial de aquecimento global em 20 anos é de 289 vezes maior em relação ao $\mathrm{CO}_{2}$. O tempo de duração do $\mathrm{CH}_{4}$ na atmosfera é de 12 anos, o do $\mathrm{N}_{2} \mathrm{O}$ é de 114 anos e o do $\mathrm{CO}_{2}$, séculos, como consta na Tabela 2.1.4 do IPCC $4^{\circ}$ Grupo (IPCC, 2012).

A maior fonte de emissões nacionais de GEE é o uso da terra e de florestas (desmatamento), que representam, em nível nacional, 60,6\% de emissões de GEE, considerando-se o ano de 2005. As emissões de GEE do Estado de São Paulo representam 6,5\% de emissões de GEE nacional (CETESB, 2011).

\subsubsection{Custos da Poluição Atmosférica para a Saúde Pública e para o Sequestro de Carbono}

Segundo Saldiva et al. (2011) a morte causa impacto à economia de U\$\$ 179.308 por pessoa, e uma internação hospitalar, de U\$ 2.472,76. Em 01/01/2011, a cotação do dólar estava em R\$ 1,65 (Banco Central, 2013).

Uma das formas de sequestro de carbono é o reflorestamento. Os custos para o reflorestamento, desconsiderando os custos da terra, por tonelada de $\mathrm{CO}_{2}$ sequestrado em projeto de reflorestamento, variam de $\mathrm{R} \$ 62,50$ a $\mathrm{R} \$ 87,53$ (Hassan, 2009).

A floresta tropical representa um sumidouro de $\mathrm{CO} 2$ na proporção de 1 a 7 toneladas de carbono por hectare ano (Nobre e Nobre, 2002).

O reflorestamento energético, no qual a celulose será utilizada para indústria siderúrgica no Brasil, tem o custo de U\$\$ 14 a U\$ 32 t/CO $\mathrm{CO}_{2}$ sequestradas (Solari Puentes, 2010). O 
sequestro geológico de carbono custa 52,3 U\$ $\$ / \mathrm{tCO}_{2}$ (Costa, 2009). Em 01/01/2009, a cotação do dólar estava em R \$ 2,33 (Banco Central, 2013).

\subsubsection{Reduções de Gases do Efeito Estufa}

A renovação total da frota de veículos com mais de 10 anos por veículos novos reduziria 69\% das emissões atmosféricas veiculares (Penna e Rezende Filho, 2012).

No Japão 3,6 milhões de veículos são reciclados anualmente, o que representa aproximadamente um montante de $5 \%$ dos veículos da frota daquele país. O usuário paga uma taxa de reciclagem juntamente com a inspeção periódica do veículo (Streit, 2012). É também proibido o estacionamento de veículos em ruas e a aquisição de veículos sem a prova da propriedade de vaga de estacionamento (MIE, 2012). No Brasil não existem dados oficiais sobre reciclagem de veículos, e é permitido livremente o estacionamento em vias públicas, exceto em alguns municípios que regulamentaram zonas de estacionamento com cobrança de taxas. A taxa de inspeção veicular no Brasil não é utilizada para fins de reciclagem de veículo, mas apenas para cobrir custos do serviço de inspeção.

Existem outras formas de redução de GEE decorrentes do uso de veículos. São medidas que incentivam o uso de meios de transporte público, uso de meios de transporte não poluentes, taxa de congestionamento, também conhecida como pedágio urbano, rodízio de veículos, taxação da quilometragem e desestímulo ao estacionamento.

\subsubsection{Políticas Públicas no Brasil}

O PROCONVE (Programa de Controle da Poluição do Ar Por Veículos Automotores) foi criado pela Resolução CONAMA 18/1986 (Brasil, 1986), ele obriga as montadoras de veículos à redução gradual da poluição atmosférica, estabelecendo parâmetros máximos de emissão de gases. O PROMOT (Programa de Controle de Poluição do Ar por Motociclos e Veículos Similares) foi criado pela Resolução CONAMA 297/02 (Brasil, 2002). De 1989 a 2009 o PROCONVE obteve a redução de $98 \%$ a emissão de gases poluentes (CETESB, 2010). O PROCONVE é eficiente para redução de emissões de poluentes atmosféricos em veículos novos, no entanto, não soluciona as emissões de poluentes atmosféricos em veículos já produzidos, desregulados.A Resolução CONAMA n. 418/09 (Brasil, 2009d) estabeleceu a obrigatoriedade de os estados instituírem Plano de Controle de Poluição Veicular (PCPV), e a mesma obrigatoriedade aplica-se aos municípios com mais de 3 milhões de veículos. Em São Paulo foram inspecionados 3.063.482 veículos, e 117.854 foram reprovados. Houve também uma evasão de $51,16 \%$ de veículos. Os resultados são significativos, com redução de mais de $50 \%$ de emissão de $\mathrm{CO}$ e quase $50 \%$ de emissão de HC, pelos carros. Nos veículos a Diesel houve redução de 13,8\% de emissão de poluentes (CONTROLAR, 2011).

O programa de Etiquetagem Nacional de Conservação de Energia de Veículos compara o consumo de combustível e emissão de dióxido de carbono de veículos, classificando os veículos em uma escala de "A" a "E". Na tabela apresentada em 17 de janeiro de 2013, o veículo nacional mais econômico foi o Renault Clio, com consumo de $10,7 \mathrm{~km} / \mathrm{l}$ de etanol e $15,8 \mathrm{~km} / \mathrm{l}$ de gasolina, em estrada, e com emissões de $87 \mathrm{gCO}_{2}$ por $\mathrm{km}$, quando abastecido com gasolina. Os três veículos mais eficientes são todos importados e híbridos: Ford Fusion, Toyota Prius e Lexus CT200h (INMETRO, 2013). O novo regime automotivo obrigou as montadoras a inscreverem-se nesse programa.

A Política Estadual de Mudanças Climáticas (PEMC), criada pela Lei Estadual de São Paulo n. 13.798, de 9 de novembro de 2009 e regulamentada pelo Decreto 55.947/2010 (São Paulo, 2010), tem por finalidade estabelecer política de mitigações dos efeitos de mudanças climáticas e redução de emissões de gases do efeito estufa, utilizando como instrumentos o registro público de emissões, fomento a atividades não poluentes, transporte sustentável e meios financeiros (São Paulo, 2012). O Plano de Transportes (PA) buscou condições para 
cumprimento da meta paulista de redução de $20 \%$ de emissão de GEE no setor de transportes, até 2020, tendo com base o ano de 2005. O incentivo para alteração do modal rodoviário para ferroviário, hidroviário e dutoviário, e incentivos ao transporte individual não motorizado mitigaria $12 \%$ da meta, que seria $5,4 \mathrm{MtCO}_{2}$. O uso de combustíveis renováveis em veículos e transporte de passageiros ede carga poderiam promover uma redução em até $25 \mathrm{MtCO}_{2}$. Essas ações poderiam ser responsáveis por atingir quase $70 \%$ da meta.

O Fundo Nacional de Mudanças Climáticas, criado pela Lei Federal n. 12.144, de 9 de dezembro de 2009 (Brasil, 2009a), tem por finalidade o financiamento de projetos de mitigações de mudanças climáticas, mediante apoio financeiro reembolsável, administrado pelo Banco Nacional de Desenvolvimento Econômico e Social (BNDES), e apoio financeiro não reembolsável, administrado pelo Ministério do Meio Ambiente. O Fundo disponibilizou, em 2011, o valor de R \$ 30 milhões em apoio não reembolsado e R \$ 200 milhões em apoio reembolsável. Em 2012, havia a previsão de obtenção de R 389 milhões.

O estado de São Paulo, no Decreto Estadual n. 58.093/2012, estabeleceu incentivos financeiros para a reciclagem de caminhões com mais de 30 anos de uso, podendo se habilitar ao programa pessoas físicas e pessoas jurídicas, como microempreendedores individuais. No programa serão financiados caminhões novos fabricados no Brasil, sem juros e mediante comprovação de reciclagem dos caminhões antigos. Os recursos para o programa são de $\mathrm{R} \$$ 45 milhões. Estima-se retirar de circulação 1.000 caminhões antigos, em Santos, com redução de 8.025 toneladas ano de emissão de GEE (CETESB, 2012a).

No Brasil e no mundo existe um movimento de incentivos ao uso da bicicleta, como lazer e como meio de transporte para o trabalho. As cidades amigas da bicicleta são: Amsterdan, Copenhagem, Barcelona, Tokyo, Berlin, Munich e Paris. Rio de Janeiro fica no $18^{\circ}$ lugar (COPEHAGENIZE, 2011). Em Copenhagem, há $350 \mathrm{~km}$ de ciclovias, e $50 \%$ da população utilizam a bicicleta diariamente. Em Paris são 20 mil bicicletas de aluguel, 1.500 estações e $371 \mathrm{~km}$ de ciclovias. O Rio de Janeiro tem $140 \mathrm{~km}$ de ciclovias (Mendes Jr., 2008Em São Paulo existem 57,5 km de ciclovias (CET, 2012).

No município de São Paulo, a Lei Municipal 12.266/2007 estabelece o Sistema Cicloviário Municipal, que trata de estacionamento de bicicletas, de ciclovias (exclusivas para bicicletas) e de ciclofaixas (faixas de veículos utilizadas para bicicletas), dentre outros. A Lei Municipal 15.649/2012 (São Paulo, 2012) tornou obrigatório, em todos os estacionamentos, o percentual de 5 a 10\% de vagas para bicicletas. O metrô de São Paulo aceita bicicletas todos os dias, a partir das 20h30, e nos sábados, a partir das $14 \mathrm{~h}$. Aos domingos e feriados, durante todo o dia, mas sempre no último vagão, com no máximo 4 bicicletas por vagão. As bicicletas dobráveis podem ser transportadas em qualquer horário (METRO, 2013).

\subsection{Tributos Sobre o Setor Automotivo no Brasil}

\subsubsection{Direito Tributário no Brasil}

O Direito é o instrumento de ação do Estado, e sua função primordial é conferir as relações sociais (Becker, 1972). O Direito é uma técnica específica de organização social coercitiva. A ordem social tem por finalidade motivar condutas, de fazer algo ou de abster-se de fazer algo. As formas utilizadas para essas condutas são a vantagem prometida ou o medo da ameaça da desvantagem (Kelsen, 2000). O Direito Tributário é a fonte de receitas necessárias à existência e ao funcionamento do Estado.

As espécies tributárias no Brasil são: imposto, taxas, contribuição de melhoria, contribuições sociais, contribuição para o custeio de iluminação pública, imposto extraordinário de guerra, empréstimo compulsório e pedágio. A receita dos impostos não tem destinação vinculada a um determinado gasto estatal, ao passo que as demais espécies têm destinação a determinada despesa governamental. 
Os princípios de Direito Tributário são garantias do cidadão contra os atos arbitrários do Estado. São os principais: Princípio da Legalidade, Igualdade, Irretroatividade, Anterioridade, Vedação ao Confisco, Liberdade de Tráfego e Capacidade Contributiva.

\subsubsection{Direito Ambiental no Brasil}

A Constituição Federal de 1988 estabeleceu um capítulo para a proteção do Meio Ambiente, outorgando direito ao meio ambiente ecologicamente equilibrado (artigo 225), bem como a defesa do meio ambiente, mediante tratamento diferenciado, conforme impacto ambiental no capítulo de ordem econômica (artigo 170). A proteção ambiental, o combate à poluição e a preservação de florestas, fauna e flora constituem competência comum dos entes federativos, Município, Estado e União (artigo 23, VI). Não existe um Código Ambiental, mas diversas leis esparsas (Brasil, 1988).

A degradação do Meio Ambiente, em desconformidade com a legislação ambiental, enseja, segundo o art. 225, $\S 3^{\circ}$, da Constituição Federal (Brasil, 1988)., às pessoas naturais e jurídicas, sanções penais e sanções administrativas, e obrigação de reparar os danos causados. Os crimes e sanções encontram-se previstos na Lei Federal n. 9.605/98 (Brasil, 1988)..

A responsabilidade por danos ambientais é objetiva, independentemente de culpa, ou seja, haverá punição somente se for comprovado o nexo de causalidade entre a ação ou a omissão do poluidor e o dano ambiental causado. Os valores arrecadados pelas multas ambientais são revertidos aos Fundos de Meio Ambiente estabelecidos pelo órgão arrecadador (Milaré, 2001). Os princípios fundamentais do Meio Ambiente são delimitados por Milaré (2001): meio ambiente ecologicamente equilibrado; natureza pública da proteção ambiental; participação comunitária; poluidor-pagador; prevenção; função socioambiental da propriedade; direito ao desenvolvimento sustentável; cooperação entre os povos.

\subsubsection{Direito Ambiental Tributário}

A solução para o conflito entre os Princípios de Poluidor Pagador e da Capacidade Contributiva é o sacrifício do Princípio da Capacidade Contributiva em favor do Princípio da Proteção ao Meio Ambiente, defendido por Taboada (2005) e Pinto (2012), mediante utilização do Princípio interpretativo da Ponderação e Proporcionalidade utilizado pelo Supremo Tribunal Federal (Brasil, 2004). Outros autores brasileiros, como Saliba (2005) e Souza (2009), afirmam que o princípio tributário da capacidade contributiva e o princípio ambiental do poluidor-pagador devem coexistir, e a degradação ambiental decorrente de um processo produtivo pode confirmar manifestação de riqueza a ser tributada.

O Tribunal Constitucional espanhol estabeleceu requisitos de validade dos tributos ambientais: i) a medida de desestímulo fiscal deve ter relação lógica com a atividade contaminante; ii) a base de cálculo desse tributo deve ter relação com a quantidade de contaminação do meio ambiente (Gonzales, 2005).

Os tributos ambientais não podem ser cobrados como punição, porque o tributo não pode ser decorrente de ato ilícito. $O$ tributo ambiental não pode ser visto como uma permissão para poluir, mas sim como um incentivo à redução da poluição mediante o uso do efeito econômico sobre o poluidor. O tributo deve ser mais um elemento de internalização de custos ambientais no preço de produtos e serviços com origem poluidora. $\mathrm{O}$ consumidor deve pagar pela reparação ambiental decorrente da fabricação de produtos adquiridos e serviços utilizados.

Os tributos (impostos, taxas e CIDE) podem ser utilizados para a proteção do Meio Ambiente mediante a concessão de benefícios fiscais e cobrança de tributos elevados sobre atividades poluentes, com o objetivo de desestimular as atividades poluentes e arrecadar fundos para recuperação do meio ambiente degradado pelo poluidor. Cada espécie de tributo terá suas características preservadas. 


\subsubsection{Tributos sobre o setor automotivo}

Os tributos sobre a produção de veículos são: ICMS, PIS/COFINS, IPI e II. Sobre o lucro das empresas incide o IRPJ/CSLL. Os tributos sobre os combustíveis são: ICMS, PIS/COFINS e CIDE. Os tributos sobre o uso de veículos são: IPVA, DPVAT, taxas e pedágio. Outras receitas governamentais são multas de trânsito e leilão de veículos.

O ICMS (Imposto sobre Circulação de Mercadorias e Serviços de Comunicação de Transporte Interestadual e Intermunicipal) tem como características principais: não cumulatividade parcial e seletividade; a arrecadação é do Estado, e 25\% são repartidos com os municípios, sendo 18,75\% (3/4) repartidos na proporção do valor adicionado nas operações realizadas no território dos municípios e 6,25\% (1/4) repartidos conforme determinado pelos estados.

O PIS (Programa de Integração Social) e COFINS (Contribuição para o Financiamento da Seguridade Social) são tributos de competência da União Federal. O PIS/COFINS é um tributo não cumulativo parcial. O PIS tem por finalidade custeio do seguro-desemprego e abono anual aos empregados com média de até 2 salários mínimos de remuneração mensal. $\mathrm{O}$ COFINS tem arrecadação destinada à Previdência Social, com despesas com saúde, previdência e assistência social.

O IPI (Imposto sobre Produtos Industrializados) é um tributo federal sobre produtos industrializados. O IPI é um tributo monofásico, não cumulativo, parcial e seletivo. Apesar de incidência monofásica, se houver sucessivas industrializações haverá sucessivas incidências. O Governo Federal estabeleceu o programa Inovar-Auto, por meio do Decreto Federal $\mathrm{n}^{\circ}$. 7.819/2012 (Brasil, 2012a), com os seguintes objetivos: fomentar inovação, desenvolvimento tecnológico, segurança, proteção ao meio ambiente, eficiência energética e qualidade dos veículos e autopeças. A Receita do IPI é repartida pela União da seguinte forma: i) $21,5 \%$ ao Fundo de Participação dos Estados e do Distrito Federal; ii) 22,5\% ao Fundo de Participação dos Municípios; iii) 3\% para programas de financiamento ao setor produtivo do Norte, Nordeste e Centro-Oeste; iv) $10 \%$ aos Estados e Distrito Federal, proporcionalmente ao valor das exportações de produtos industrializados. A União Federal fica com $43 \%$ do valor arrecadado.

O Imposto de Importação é um tributo federal que estabelece normas e procedimentos de declaração e valor aduaneiro (Paulsen e Melo, 2007). A Receita desse tributo não é repartida, fica exclusivamente com a União Federal. Não se aplica o Imposto de Importação aos veículos fabricados nos países do Mercosul. Há também um acordo com veículos provenientes do México, que têm uma cota de importação até o ano de 2015.

A CIDE (Contribuição de Intervenção no Domínio Econômico) é um tributo sobre a importação e comercialização de petróleo e seus derivados, gás natural e etanol. A destinação da CIDE - combustíveis será: i) subsídios para o preço do combustível; ii) financiamento de projetos ambientais relacionados à indústria do petróleo e gás; iii) financiamento de infraestrutura de transportes. Considerando os anos de 2002 a 2008, foram destinados ao transporte $\mathrm{R} \$ 28,8$ bilhões e, para o Meio Ambiente, no mesmo período, $\mathrm{R} \$ 95$ milhões de reais, que correspondem a apenas 2,79\% dos recursos (Dantas, 2009). A receita da CIDE Combustíveis é repartida da seguinte forma: 29\%, para Estados e Distrito Federal; os municípios ficam com $25 \%$ do valor distribuído aos Estados; e, a União fica com os $71 \%$ restantes do valor arrecadado.

As empresas, no Brasil, pagam o Imposto de Renda Pessoa Jurídica (IRPJ) e a Contribuição Social sobre o Lucro Líquido (CSLL). A destinação da receita do IRPJ é idêntica à do IPI. A destinação da receita da CSLL é a seguridade social.

O IPVA (Imposto sobre a Propriedade de Veículo Automotor) é um imposto de competência dos Estados. Cada estado estabelece a legislação sobre esse tributo, e $20 \%$ da receita são direcionados ao Fundo de Manutenção e Desenvolvimento da Educação Básica e 
Valorização dos Profissionais da Educação (FUNDEB). O restante, 50\%, fica com o município onde o veículo está registrado.

O seguro DPVAT (Danos Pessoais Causados por Veículos Automotores de via Terrestre ou por sua carga a Pessoas Transportadas ou não), denominado de seguro-obrigatório, tem por finalidade indenizar, em casos de acidente de trânsito, em caso de morte e invalidez permanente, ou reembolsar a vitima por despesas médicas. Da arrecadação do DPVAT, 50\% são repassados ao Ministério da Saúde, 45\% ficam com a Seguradora Líder, para pagamento de indenizações, e 5\% são direcionados ao DENATRAN, para custeio de programas de prevenção de acidentes de trânsito (DPVAT, 2012).

Os veículos automotores pagam a taxa de registro de veículo, transferência, taxa de emplacamento e lacração, licenciamento anual e inspeção veicular. O Relatório do Tribunal de Contas do Estado de São Paulo indica que há desproporção entre as receitas das taxas e o custo dos serviços prestados pelo DETRAN SP. No ano de 2011 as receitas das taxas de serviços do DETRAN foram de R \$2,4 bilhões, e as despesas totais do DETRAN foram de R\$ 347 milhões, ou seja, as despesas são 14,46\% da arrecadação (TCE, 2011). Uma notória inconstitucionalidade.

O pedágio encontra-se previsto no artigo 150, V, da Constituição Federal (Brasil, 1988). Quanto à análise de constitucionalidade, o Supremo Tribunal Federal, no RE 181.475-6 entendeu que o pedágio é uma taxa, sendo uma contraprestação pela utilização de rodovia pública (Brasil, 2009c). O Supremo Tribunal Federal, no Ag.REG, no AI 531.529, tem considerado a natureza jurídica do pedágio de acordo com o uso facultativo ou obrigatório da rodovia para deslocamento, ou seja, se o usuário não tem alternativa para deslocamento o pedágio é considerado uma taxa, porque obrigatório, sendo vinculado a necessidade de Lei para o instituir, ao passo que, se há rotas alternativas, o pedágio é considerado uma tarifa, não submetida ao Princípio da Legalidade.

O Imposto sobre Operações Financeiras (IOF) incide sobre operações de seguro, inclusive de veículos. O IOF sobre seguros não é repartido, ficando a receita de sua arrecadação exclusivamente para a União Federal.

As multas de trânsito não são tributos, mas uma fonte de receita que deveria ser destinada exclusivamente a gastos com sinalização, engenharia de tráfego, de campo, policiamento, fiscalização e educação de trânsito. O percentual de 5\% das multas é destinado ao DENATRAN, para programa de segurança e educação no trânsito, denominado de FUNSET. A arrecadação com multas, em 2011, foi de R $\$ 6$ bilhões.

Os veículos apreendidos ou removidos a qualquer título e não reclamados no prazo de 90 (noventa) dias devem ser leiloados. O montante do leilão deverá ser utilizado para pagamento de tributos, despesas de remoção e estadia e multas de trânsito. O saldo, se houver, deve ser depositado ao proprietário do veículo, conforme artigo 14 da Resolução CONTRAN 331/09 (Brasil, 2009c). Em 2010 e 2011 houve um saldo em conta governamental de R\$ 15 milhões, saldo este que deveria ser devolvido aos proprietários (TCE, 2012).

A carga tributária na fabricação de veículos no ano de 2011 foi de 30,6\% para um veículo popular, de $48,6 \%$ para um veículo mais luxuoso e de $18,02 \%$ para caminhões e ônibus. Os veículos importados são acrescidos de 35\% de Imposto de Importação. Uma moto com menos de 250cc fabricada na Zona Franca de Manaus tem 21,65\% de tributos; com mais de 250cc, tem $28,5 \%$ de carga tributária. Uma moto com mais de $250 \mathrm{cc}$ fabricada fora da Zona Franca de Manaus tem uma carga tributária de $69,25 \%$. Às motos importadas são acrescidos $20 \%$ de imposto de Importação.

Quanto aos combustíveis, há uma carga tributária de 34\% para gasolina, 22\% para o etanol e $21 \%$ para o diesel.

A carga tributária anual sobre uso de um veículo popular zero $\mathrm{km}$, no valor de $\mathrm{R} \$$ 22.000,00, em São Paulo, equivale a 5,28\%, anual, incluindo-se o IPVA, DPVAT, taxa de 
licenciamento, inspeção veicular, IOF sobre o seguro, no valor total de R\$ 1.162,02. Considerando todos os gastos anuais com o uso do veículo, com tributos e despesas, o valor anual do total de despesas de um veículo popular é de $\mathrm{R} \$ 6.312,02$, que corresponde a $28,69 \%$ do valor do veículo.

\subsubsection{Custo das obrigações acessórias e a carga tributária}

O cumprimento das obrigações acessórias fiscais, com pagamentos de softwares, mão de obra, especialistas tributários e advogados, custa aproximadamente 2,6\% do preço dos produtos no Brasil (FIESP, 2011). Segundo o Banco Mundial (2012), o Brasil é o país com maior burocracia fiscal do mundo, com necessidade de 2.600 horas de trabalho/ano para apuração e pagamento de tributos. A média de países desenvolvidos, como Alemanha, Canadá, Chile, França, Espanha, Japão, Itália e Suíça, é de 200 horas ano.

A carga tributária brasileira total, no ano de 2010, foi de 35,13\% do PIB (Produto Interno Bruto), superior à carga de países desenvolvidos, como Japão (26,9\%), Suíça $(29,8 \%)$, Canadá (31\%), Estados Unidos $(24,80 \%)$, e inferior a outros países, como França $(43,15 \%)$, Dinamarca $(44,06 \%)$, Noruega $(42,80 \%)$; no entanto, o retorno dos tributos ao cidadão é o mais baixo, considerando 30 países com maior tributação no mundo (IBPT, 2012).

No ano de 2011, a carga tributária na fabricação de veículos foi de $\mathrm{R} \$ 76$ bilhões; no uso dos veículos, de $\mathrm{R}$ \$ 65 bilhões; na aquisição de combustíveis, de $\mathrm{R}$ \$ 67,9 bilhões.

\subsubsection{Totais de Receitas e Despesas do Governo Brasileiro}

As receitas governamentais brasileiras consolidadas, do ano de 2011, são de $\mathrm{R} \$ 2,5$ trilhões de reais. As principais fontes de receitas são 26,87\% de impostos, $21,67 \%$ de contribuições sociais e $26,80 \%$ de receitas de capitais. As despesas governamentais brasileiras consolidadas, do ano de 2011, são de R \$ 2,5 trilhões de reais. As principais despesas são com educação $(8,6 \%)$, saúde $(7,87 \%)$, administração $(3,15 \%)$, segurança pública $(2,13 \%)$ e transporte (2,05\%). Meio Ambiente recebeu apenas 0,37\% (Tesouro Nacional, 2012).

\section{MATERIAL E MÉTODOS}

A pesquisa foi descritiva e realizada de maio de 2012 a janeiro de 2013.. As fontes gerais de documentos foram documentos do governo brasileiro, publicações técnicas do meio automotivo e documentos científicos: artigos, teses, dissertações e livros.

$\mathrm{Na}$ primeira etapa realizou-se um comparativo ambiental e econômico de combustíveis (etanol, gasolina, diesel, GNV, eletricidade) e meios de transporte (individual ou coletivo).

A emissão de GEE foi calculada com utilização da planilha eletrônica GHG Protocol (FGV, 2012), para inventário de emissões, desconsiderando o $\mathrm{CO}_{2}$ produzido de biomassa, com base no consumo de combustível de cada um dos tipos de transporte. Quanto ao metrô de São Paulo, foram utilizados dados de GEE por km do inventário de emissões (METRO, 2011). Para calcular o GEE dos meios de transporte foi utilizada a média nacional de $44 \mathrm{~km}$ diários. Para ônibus foram considerados 40 passageiros, porque sua finalidade é o transporte coletivo, ao passo que, no transporte individual, de carro ou moto, haverá no mínimo um passageiro. Para emissão de GEE de veículo elétrico foram utilizados dados do Sistema Elétrico Nacional para 2011 - 0,02912 $\mathrm{tCO}_{2} / \mathrm{mwh}$ (Brasil, 2012b).

Na segunda etapa os dados de emissões atmosféricas médias de veículos leves fabricados nos anos de 2003 (CETESB, 2011) e 2013 (INMETRO, 2013), para veículos a gasolina foram compilados. Para veículo movido a etanol, para o ano de 2013 foram utilizadas as emissões obtidas no Programa GHG Protocol (FGV, 2012), e, para o ano de 2003, utilizou-se o redutor de $32 \%$ no consumo. Os dados de $\mathrm{CO}_{2}$ na fabricação são da Ford (FORD, 2012) e de fabricante de veículos na Inglaterra (SMMT, 2012). 
Na terceira e última etapa foi feita a proposta de reestruturação da tributação sobre veículos e combustíveis, no Brasil, para o desenvolvimento sustentável. A proposta de reestruturação tributária obedeceu aos seguintes critérios: i) não reduzir a receita governamental da União Federal, Estados e Municípios e não aumentar a carga tributária brasileira; ii) classificar os veículos por combustíveis e tecnologias automotivas de redução de emissões atmosféricas; iii) aplicar a receita dos tributos utilizadas para reparação da poluição atmosférica veicular, com fiscalização, compensação ambiental e reparação de custos de saúde gerados pela poluição; iv) reduzir a quantidade de tributos, se possível, unificando-os; v) promover alterações em políticas públicas, que devem atuar em conjunto com a tributação, para aumentar sua eficiência.

\section{RESULTADOS}

O primeiro resultado do comparativo ambiental e econômico indica, para fins econômicos, o transporte de metrô e ônibus como mais eficiente; no entanto, para fins ambientais de emissão de $\mathrm{CO}$, o veículo com menor emissão por quilômetro é uma moto popular 150 cilindradas, quando movida a etanol, ficando em segundo o veículo individual movido a etanol e em terceiro o transporte de metrô. Os resultados estão na Tabela 1.

Tabela 1. Resultado do comparativo ambiental e econômico de combustíveis $-\mathrm{CO}_{2}$ por usuário.

\begin{tabular}{|c|c|c|c|c|c|c|c|c|c|c|}
\hline \multirow[b]{3}{*}{ veículo } & \multicolumn{10}{|c|}{ comparativo de eficiência energética e emissão de gases } \\
\hline & \multicolumn{3}{|c|}{ emissão de GEE } & \multicolumn{5}{|c|}{$16.091 \mathrm{~km} / \mathrm{ano}$ - 44 km/dia - GHC Protocol - por usuário } & \multicolumn{2}{|c|}{ fator } \\
\hline & combustível & $\begin{array}{c}\begin{array}{c}\text { consumo } \\
(\mathrm{km} / \mathrm{l})\end{array} \\
\end{array}$ & $\mathrm{gCO} 2 / \mathrm{km}$ & litros & $\begin{array}{c}\mathrm{CO2e} \\
(\mathrm{kg})\end{array}$ & $\begin{array}{c}\text { Combustível } \\
-\mathbf{R} \$\end{array}$ & $\begin{array}{c}\text { Despesas - } \\
\text { R\$ }\end{array}$ & $\begin{array}{c}\text { Total/desp } \\
-\mathbf{R} \$\end{array}$ & econômico & ecológico \\
\hline \multirow{3}{*}{$\begin{array}{l}\text { Fiat Siena } \\
\text { Tetra-fuel }\end{array}$} & gasolina $\mathrm{C}$ & 17,80 & 98,42 & 903,99 & $1.583,72$ & $2.467,89$ & $3.392,02$ & $5.859,91$ & 2,68 & 203,04 \\
\hline & etanol & 12,20 & 1,09 & $1.318,93$ & 17,61 & $2.637,87$ & $3.392,02$ & $6.029,89$ & 2,75 & 2,26 \\
\hline & GNV & 22,40 & 93,95 & 718,35 & $1.511,73$ & $1.149,36$ & $3.392,02$ & $4.541,38$ & 2,07 & 193,81 \\
\hline Estimado & diesel & 15,79 & 161,42 & $1.018,80$ & $2.597,46$ & $2.068,16$ & $3.392,02$ & $5.460,18$ & 2,49 & 333,01 \\
\hline $\begin{array}{l}\text { LEAF - } \\
\text { Nissan }\end{array}$ & eletricidade & $5 \mathrm{kwh}$ & 5,82 & $3.218,20$ & 93,65 & $1.222,92$ & $3.172,02$ & $4.394,94$ & 2,01 & 12,01 \\
\hline Honda CG & gasolina & 41,20 & 42,52 & 390,56 & 684,23 & $1.066,22$ & $1.820,61$ & $2.886,83$ & 1,32 & 87,72 \\
\hline $\begin{array}{l}\text { MIX } 150 \\
\text { Flex }\end{array}$ & etanol & 27,55 & 0,48 & 584,07 & 7,80 & $1.168,13$ & $1.820,61$ & $2.988,74$ & 1,36 & 1,00 \\
\hline metro SP & & & 2,00 & & 32,18 & & $2.190,00$ & $2.190,00$ & 1,00 & 4,13 \\
\hline $\begin{array}{l}\text { ônibus / } 40 \\
\text { passageiros }\end{array}$ & diesel & 3,00 & 21,25 & 134,09 & 341,87 & & $2.190,00$ & $2.190,00$ & 1,00 & 43,83 \\
\hline
\end{tabular}

O segundo resultado trata da reciclagem da frota, medindo as diferenças de emissões entre um veículo fabricado no ano de 2003 e um veículo novo, fabricado no ano de 2013, considerando o $\mathrm{CO}_{2}$ emitido na fabricação de um veículo $\left(0,805 \mathrm{tCO}_{2}\right.$ por veículo). $\mathrm{O}$ resultado para o veículo leve movido a gasolina indica a viabilidade da reciclagem da frota, compensando ambientalmente, no prazo de 1,25 a 0,47 ano, e reduzindo a emissão de mais de $1 \mathrm{tCO}$ /ano. Para o veículo leve movido a etanol, em razão da baixa emissão de $\mathrm{CO}_{2}$ a troca compensaria apenas em 95 anos, com redução de apenas 8 kg CO $2 / a n o$, conforme demonstra a Tabela 2. 
Tabela 2. Resultado da redução de $\mathrm{CO}_{2}$ na aquisição de veículo novo - anos para troca.

\begin{tabular}{llcccc}
\hline veículo & fonte & $\mathbf{g C O}_{\mathbf{2}} / \mathbf{k m}$ & $\begin{array}{c}\mathbf{1 6 . 0 9 1} \mathbf{~ k m} / \mathbf{a n o} \\
\mathbf{g C O}\end{array}$ & $\begin{array}{c}\text { redução } \\
\mathbf{C O}_{\mathbf{2}}\end{array}$ & $\begin{array}{c}\text { Anos - } \\
\text { troca novo }\end{array}$ \\
\hline veículo 2003 - etanol & estimado & 1,61 & 25.958 & & \\
veículo 2013 - etanol & GHC Protocol & 1,09 & 17.539 & $8.418,81$ & 95,62 \\
veículo 2003 - gasolina & CETESB - média & 194,00 & 3.121 .654 & & \\
veículo 2013 - gasolina & INMETRO - média & 131,42 & 2.114 .679 & $1.006 .974,7 \varepsilon$ & 1,25 \\
veículo 2013 - baixa emissão & INMETRO - Clio & 87,00 & 1.399 .917 & $1.721 .737,00$ & 0,47 \\
\hline
\end{tabular}

O resultado indica ser favorável a reciclagem de veículos quando se utiliza o combustível gasolina. Se o consumo é de etanol, não se indica a reciclagem de veículos.

Para o resultado pretendido, de reestruturação tributária no setor automotivo, após análise da arrecadação e despesas do governo brasileiro são realizadas as seguintes considerações:

i) Unificação do ICMS, PIS/COFINS e IPI, criando-se o IVA (imposto sobre valor agregado) federal automotivo. A arrecadação poderá ser centralizada na União Federal. Não haveria nenhuma perda tributária aos entes federativos, com a distribuição para: Previdência (23\%), União (6\%), Estados (52\%), Municípios (19\%). Na distribuição entre estados e municípios seria aplicado o critério de população. Benefícios de redução de custos de apuração de impostos a empresas e redução de custos governamentais de fiscalização, sem qualquer perda de arrecadação.

ii) Unificar o Imposto de Renda para Pessoa Jurídica com a Contribuição Social sobre o Lucro, de forma que as empresas paguem apenas um tributo e apurem apenas um tributo sobre o lucro. A divisão da receita da previdência e da União, estados e municípios seria feita pela Receita Federal. Benefícios são redução de custos de apuração e redução de tempo de fiscalização.

iii) Extinção do IPVA e incorporação da arrecadação na CIDE-combustível.

iv) Extinção do ICMS e PIS/COFINS sobre combustíveis. Inclui-se na arrecadação da CIDE-combustível o valor que seria arrecadado com o IPVA e o ICMS e PIS/COFINS sobre combustíveis. Aumenta-se a carga tributária da gasolina de $45 \%$ para 56\%, conforme Tabela 3. A vinculação da CIDE Combustíveis de $40 \%$ à área de meio ambiente, para fiscalização, manutenção de parques e reflorestamento, possibilitaria aumentar o empenho ao Meio Ambiente, de $\mathrm{R} \$ 9,2$ bilhões anuais para $\mathrm{R} \$ 30,65$ bilhões, atividades estas que sequestram GEE. O restante arrecadado seria assim destinado: $20 \%$ para a educação, $20 \%$ para a saúde e $20 \%$ para transportes. A cobrança deveria ser por substituição tributária, nas usinas de combustíveis. A distribuição da receita seria: Previdência (17\%), União (8\%), Estados (50\%), Municípios (25\%). A divisão das receitas entre Estados e Municípios seguiria a regra de $75 \%$ da população e $25 \%$ pelo tamanho do território, porque a finalidade desse tributo é compensar pela poluição gerada pelo uso do combustível e promover a preservação ambiental nos estados e municípios com grande território. 
Tabela 3. Proposta de CIDE-combustíveis arrecadação.

\begin{tabular}{|c|c|c|c|c|c|c|c|c|c|}
\hline combustível & $\begin{array}{c}\text { consumo } \\
\text { Brasil mil I } \\
\left(\text { GNV m}^{3}\right)\end{array}$ & $\begin{array}{c}\text { preço } \\
2011 \text { - } \\
\text { R\$ }\end{array}$ & $\begin{array}{c}\text { combustíve } \\
\text { is - } \mathbf{R} \$ \text { bi }\end{array}$ & $\begin{array}{c}\text { tributos } \\
-\mathrm{R} \$ \mathrm{bi} \\
\text { atual }\end{array}$ & $\begin{array}{l}\text { carga } \\
\text { atual }\end{array}$ & $\begin{array}{c}\text { arrecadação } \\
\text { proposta - } \\
\text { R\$ bi }\end{array}$ & $\begin{array}{c}\text { carga } \\
\text { proposta }\end{array}$ & $\begin{array}{c}\text { preço } \\
\text { combustível }\end{array}$ & $\begin{array}{c}\text { aumento - } \\
\mathbf{R} \$\end{array}$ \\
\hline gasolina $\mathrm{C}$ & 30.760 .000 & 2,73 & 83,97 & 37,90 & $45 \%$ & 58,64 & $56 \%$ & 3,40 & 0,67 \\
\hline etanol & 14.906 .000 & 2 & 29,81 & 4,50 & $15 \%$ & 6,33 & $20 \%$ & 2,12 & 0,12 \\
\hline GNV & 1.972 .095 & 1,6 & 3,16 & 0,50 & $16 \%$ & 0,75 & $22 \%$ & 1,73 & 0,13 \\
\hline diesel & 52.264 .000 & 2,03 & 106,10 & 25,00 & $24 \%$ & 27,03 & $25 \%$ & 2,07 & 0,04 \\
\hline total & & & 223,04 & 67,90 & & 92,75 & & & \\
\hline
\end{tabular}

v) Caso parte da receita da área de meio ambiente, $\mathrm{R} \$ 1$ bilhão, por exemplo, fosse investida em manutenção de florestas, poderiam ser sequestrados $41.666 \mathrm{tCO} /$ ano, e caso outra parte fosse investida em reflorestamento, sem contar os custos de aquisição da terra, com mais $\mathrm{R} \$ 1$ bilhão seria possível sequestrar 11.424.654 $\mathrm{tCO}_{2}$.

vi) As multas de trânsito deveriam ser aplicadas integralmente em segurança viária, conforme determina a legislação. $\mathrm{O}$ administrador público que não o fizesse deveria ser condenado por crime de responsabilidade.

vii) As taxas cobradas pelos estados, para registro, emplacamento e licenciamento devem ser necessárias para a realização dos serviços. As taxas cobradas que excedem desproporcionalmente ao custo dos serviços são inconstitucionais.

viii) As alterações propostas dependem de emenda constitucional. Essas mudanças seriam aplicadas somente aos tributos sobre o setor automotivo, e, se bem aplicadas, poderiam ser estendidas a todos os demais setores econômicos.

ix) Inspeção veicular deveria ser obrigatória para todo o Brasil, em razão de sua eficiência na redução de emissões atmosféricas por veículos usados, e a cobrança deveria ser junto ao licenciamento anual.

x) Devem ser unificados os Programas Nota Verde do IBAMA com o Etiquetagem Veicular do INMETRO, para que o consumidor possa comparar os veículos e a emissão de todos os gases poluentes, como $\mathrm{HC}, \mathrm{CO}$ e $\mathrm{NOx}$, além do $\mathrm{CO}_{2}$, que já consta na etiquetagem veicular do INMETRO. Deve ser feita uma lista única com todos os dados, a ser divulgada semestral ou anualmente.

\section{CONCLUSÕES}

Os resultados de comparativo de combustíveis demonstraram que uma moto e um veículo movidos a etanol emitem menos GEE, em comparação com a emissão de um veículo elétrico e com a do metrô de São Paulo. O veículo movido a gasolina, diesel e GNV emitem mais GEE que os veículos movidos a etanol/eletricidade. Para fins ambientais, os melhores meios de transporte são a moto e o veículo movidos a etanol/eletricidade e o uso do metrô em São Paulo. Um ônibus com 40 passageiros movido a diesel emite $22 \%$ de GEE, em relação a 40 veículos movidos a gasolina. Um ônibus com 40 passageiros movido a diesel emite 19 vezes mais GEE, em relação a 40 veículos movidos a etanol. Para fins econômicos, o transporte coletivo em ônibus e metrô mostrou-se mais econômico, em razão das despesas e tributos do transporte individual. Deve ser incentivado o uso do etanol/eletricidade e desestimulado o uso da gasolina, GNV e diesel, para o transporte individual ou coletivo.

Os resultados da pesquisa para reciclagem da frota demonstraram que a troca e reciclagem de um veículo com 10 anos de uso por um veículo novo, considerando-se o uso da gasolina para um veículo de baixa emissão, como é o caso do Renault Clio, compensaria os 
GEE emitidos durante a fabricação do veículo no período de apenas 6 meses. Já a troca de veículo movido a etanol de mais de 10 anos por um novo compensaria o GEE emitido na fabricação do veículo em 95 anos de uso.

Foi demonstrada a possibilidade de unificação dos tributos ICMS PIS/COFINS e IPI, na aquisição dos veículos, não havendo qualquer impacto de aumento ou redução da carga tributária, no entanto reduzindo os custos das empresas na apuração destes tributos e facilitando a arrecadação tributária.

Foi proposta a extinção do IPVA e a extinção do PIS/COFINS e ICMS sobre combustíveis, mantendo-se apenas a CIDE-Combustíveis, que pode vincular suas receitas a atividades de saúde, educação, transporte e meio ambiente. Não haverá perdas aos entes públicos, porque será incorporada a divisão de receitas do IPVA, PIS/COFINS e ICMS sobre combustíveis. A área de Meio Ambiente no Brasil passaria a receber adicionalmente $\mathrm{R} \$ 21$ bilhões de reais por ano, com a finalidade de aumentar a fiscalização, preservação de florestas e projetos de reflorestamento, o que compensaria em parte a emissão dos poluentes atmosféricos dos veículos, melhorando a qualidade de vida dos brasileiros.

Foi proposto também que as empresas continuem a emitir Nota Fiscal Eletrônica e que, com base nesses dados, a União federal apure os tributos. Com isso, reduz-se o custo da apuração dos tributos, tornando o produto brasileiro mais barato e facilitando a concorrência com produtos importados.

Quanto aos programas públicos de emissões atmosféricas veiculares, o PROCONVE é eficiente, e a inspeção veicular eficiente deve ser obrigatória em todo o Brasil. Os programas Nota Verde do IBAMA e Etiquetagem do INMETRO devem ser totalmente unificados. As políticas estaduais e federais de mudanças climáticas precisam ser aplicadas. A Reciclagem de caminhões é uma excelente ferramenta, em São Paulo, para redução de emissões. O incentivo ao uso da bicicleta é um importante instrumento para redução de emissões de poluentes atmosféricas e de trânsito.

Por fim, os objetivos do presente trabalho foram alcançados com comparativo de emissões dos combustíveis, proposta de programa de reciclagem de veículos, proposta de reestruturação tributária no setor automotivo e sugestões para aprimoramento das políticas públicas de redução de emissões de poluentes atmosféricos automotivos. As propostas estão em conformidade com o princípio do desenvolvimento sustentável, porque estimulam a economia com a produção de veículos, visam à manutenção de empregos ou o oferecimento de novos empregos e a redução de emissões de poluentes atmosféricos.

Concentraram-se os estudos na extinção do IPVA e na extinção do ICMS/PIS/COFINS sobre combustíveis e sua incorporação à CIDE combustíveis, de forma que não foi alcançado o objetivo de diferenciar a tributação (alíquotas e benefícios fiscais) de veículos com novas tecnologias, que dependem de outro estudo, no qual se compare cientificamente a redução de emissões atmosféricas para cada uma das novas tecnologias.

\section{REFERÊNCIAS}

AGÊNCIA NACIONAL DO PETRÓLEO, GÁS NATURAL E BIOCOMBUSTÍVEIS (Brasil). Resoluções ANP. 2010. Disponível em: www.anp.gov.br. Acesso em: 26 jan. 2013.

ASSOCIAÇÃO NACIONAL DOS FABRICANTES DE VEÍCULOS AUTOMOTORES ANFAVEA. Anuário da indústria automobilística - 2012a. Disponível em: http://www.anfavea.com.br. Acesso em: 29 set. 12. 
ASSOCIAÇÃO NACIONAL DOS FABRICANTES DE VEÍCULOS AUTOMOTORES ANFAVEA. Diesel e emissões: a nova legislação 2012b. Disponível em: http://www.anfavea.com.br/documentos/CARTILHAproconveSPREAD.pdf. Acesso em: 23 out. 2012.

BANCO CENTRAL (Brasil). Taxas de câmbio. Disponível em http://www4.bcb.gov.br/pec/taxas/port/PtaxRPesq.asp?idpai=TXCOTACAO. Acesso em: 01 maio 2013.

BECKER, A. A. Teoria geral do direito tributário. São Paulo: Saraiva, 1972.

BRASIL. Casa Civil. Subchefia para Assuntos Jurídicos. Decreto $\mathrm{n}^{\circ} 7.819$ de 03 de outubro de 2012a. Regulamenta os arts. 40 a 44 da Lei no 12.715, de 17 de setembro de 2012, que dispõe sobre o Programa de Incentivo à Inovação Tecnológica e Adensamento da Cadeia Produtiva de Veículos Automotores - INOVAR-AUTO, e os arts. $5^{\circ}$ e $6^{\circ}$ da Lei $\mathrm{n}^{\circ}$ 12.546, de 14 de dezembro de 2011, que dispõe sobre redução do Imposto sobre Produtos Industrializados, na hipótese que especifica. Diário Oficial [da] União, Poder Executivo, 03 de out. 2012, Seção I, p. 1.

BRASIL. Casa Civil. Subchefia para Assuntos Jurídicos. Lei n ${ }^{\circ} 12.114$ de 09 de dezembro de 2009a. Cria o Fundo Nacional sobre mudança do clima, altera os arts. $6^{\circ}$ e 50 da lei 9.478, de 6 de agosto de 1997, e dá outras providências. Diário Oficial [da] União, Poder Executivo, 10 de dez. 2009, Seção I, p. 9.

BRASIL. Conselho Nacional de Política Energética - CNPE. Resolução CNPE no 6, de 16.9.2009b. Estabelece em cinco por cento, em volume, o percentual mínimo obrigatório de adição de biodiesel ao óleo diesel comercializado ao consumidor final, de acordo com o disposto no art. $2^{\circ}$ da Lei ${ }^{\circ} 11.097$, de 13 de janeiro de 2005. Disponível em:

http://nxt.anp.gov.br/NXT/gateway.dll/leg/folder_resolucoes/resolucoes_cnpe/2009/rcn pe\%206\%20-\%202009.xml. Acesso em: 2 fev. 2014.

BRASIL. Conselho Nacional de Trânsito - CONTRAN. Resolução CONAMA no 331 de 14 de agosto de 2009c. Dispõe sobre uniformização do procedimento para realização de hasta pública dos veículos retidos, removidos e apreendidos, a qualquer título, por Órgãos e Entidades componentes do Sistema Nacional de Trânsito, conforme o disposto no artigo 328 do Código de Trânsito Brasileiro (CTB). Disponível em: http://www.denatran.gov.br/download/Resolucoes/RESOLUCAO_CONTRAN_331_09 .pdf. Acesso em: 2 fev 2014.

BRASIL. Conselho Nacional do Meio Ambiente. Resolução CONAMA no 18 de 06 de maio de 1986. Dispõe sobre a criação do Programa de Controle de Poluição do Ar por Veículos Automotores - PROCONVE. Disponível em: http://www.mma.gov.br/port/conama/legiabre.cfm?codlegi=41. Acesso em: 2 fev. 2014.

BRASIL. Conselho Nacional do Meio Ambiente. Resolução CONAMA no 3, de 28 de junho de 1990. Dispõe sobre padrões de qualidade do ar, previstos no PRONAR. Disponível em: http://www.mma.gov.br/port/conama/legiabre.cfm?codlegi=100. Acesso em: 2 fev 2014. 
BRASIL. Conselho Nacional do Meio Ambiente. Resolução CONAMA no 297, de 26 de fevereiro de 2002. Estabelece os limites para emissões de gases poluentes por ciclomotores, motociclos e veículos similares novos. Disponível em: http://www.mma.gov.br/port/conama/legiabre.cfm?codlegi=294. Acesso em: 2 fev 2014.

BRASIL. Conselho Nacional do Meio Ambiente. Resolução no 418, de 25 de novembro de 2009d. Dispõe sobre critérios para a elaboração de Planos de Controle de Poluição Veicular - PCPV e para a implantação de Programas de Inspeção e Manutenção de Veículos em Uso - I/M pelos órgãos estaduais e municipais de meio ambiente e determina novos limites de emissão e procedimentos para a avaliação do estado de manutenção de veículos em uso. Disponível em: http://www.mma.gov.br/port/conama/legiabre.cfm?codlegi=618. Acesso em: 2 fev 2014.

BRASIL. Constituição Federal de 1988. Disponível em: http://www.planalto.gov.br/ccivil_03/constituicao/constituicao.htm. Acesso em: 3 ago. 2011.

BRASIL. Ministério da Ciência e Tecnologia. Sistema Interligado Nacional - SIN. Fator de utilização em inventário privados. 2012b. Disponível em: http://www.mct.gov.br/index.php/content/view/321144.html. Acesso em: 10 out. 2012.

BRASIL. Ministério do Meio Ambiente. Mudanças climáticas. Brasília, 2011.

COMPANHIA DE ENGENHARIA DE TRAFEGO - CET (São Paulo). Bicicleta: um meio de transporte. 2012a. Disponível em: <http://www.cetsp.com.br/consultas/bicicleta/umnovo-meio-de-transporte-a-bicicleta.aspx >. Acesso em: 30 dez. 2012.

COMPANHIA DE TECNOLOGIA DE SANEAMENTO AMBIENTAL - CETESB. Governo lança linha de crédito para a troca de caminhões poluentes. 31 maio 2012b. Disponível em: http://www.cetesb.sp.gov.br/noticia/399,Noticia. Acesso em: 10 out 2012.

COMPANHIA DE TECNOLOGIA DE SANEAMENTO AMBIENTAL - CETESB. Inventário de emissões antrópicas de gases de efeito estufa diretos e indiretos do estado de São Paulo. 2011. Disponível em: http://www.cetesb.sp.gov.br/userfiles/file/mudancasclimaticas/geesp/file/docs/publicaca o/inventario_estadual/sao_paulo/inventario_sp/Primeiro_Inventario_GEE_WEB_Segun da-Edicao-v1.pdf. Acesso em: 28 maio 2012.

COMPANHIA DE TECNOLOGIA DE SANEAMENTO AMBIENTAL - CETESB. Qualar. 2012c. Disponível em: 〈http://www.cetesb.sp.gov.br/ar/qualidade-do-ar/32-qualar〉. Acesso em: 30 dez. 2012.

COMPANHIA DE TECNOLOGIA DE SANEAMENTO AMBIENTAL - CETESB. Relatório de qualidade do ar no estado de São Paulo - 2009. São Paulo, 2010. Disponível em: http://www.cetesb.sp.gov.br/Ar/publicacoes.asp. Acesso em: 28 maio 2011.

COMPANHIA DO METROPOLITANO DE SÃO PAULO - METRO. Bicicleta no Metro. 2012. Disponível em: < http://www.metro.sp.gov.br/sua-viagem/bicicletas/bicicletametro.aspx>. Acesso em: 30 dez. 2012. 
COMPANHIA DO METROPOLITANO DE SÃO PAULO - METRO. Inventário de emissões de gases do efeito estufa - 2010. 2011. Disponível em: www.metro.sp.gov.br. Acesso em: 10 ago. 2012.

CONTROLAR. Inspeção ambiental veicular: relatório anual 2010. São Paulo, 2011. Disponível em: <http://www.controlar.com.br/pdf/relatorio_anual_2010_final.pdf>. Acesso em: 10 nov. 2012.

COPEHAGENIZE. Bicycle friendly cities, 2011. Disponível em: http://www.copenhagenize.eu/index/index.html. Acesso em: 23 out. 2012.

COSTA, I. V. L. da. Análise do potencial técnico do sequestro geológico de $\mathrm{CO}_{2}$ no setor petróleo no Brasil. 2009. Dissertação (Mestrado em Planejamento Energético) Universidade Federal do Rio de Janeiro, Rio de Janeiro, 2009.

DANTAS, K. E. G. A vinculação de receitas pós-constituição federal de 1988: rigidez ou flexibilidade da política fiscal? O caso da CIDE-Combustíveis. In: BRASIL. Ministério da Fazenda. Tesouro Nacional. IX Prêmio Tesouro Nacional. 2009. Disponível em: http://www3.tesouro.fazenda.gov.br/Premio_TN/XIVPremio/qualidade/3qualidadeXIV PTN/Monografia_Tema4_Karlo_Eric.pdf. Acesso em: 30 dez. 2012.

DPVAT. Pagamento anual do seguro: informe-se, 2012. Disponível em http://www.dpvatsegurodotransito.com.br/pagamento-anual-do-seguro.aspx. Acesso em: 01 dez. 2012.

FEDERAÇÃO DAS INDÚSTRIAS DO ESTADO DE SÃO PAULO - FIESP. Carga extra na indústria brasileira: parte 1 : custos do sistema tributário. Setembro de 2011. Disponível em: www.fiesp.com.br/arquivo-download/?id=1863. Acesso em: $31 \mathrm{dez}$. 2012.

FORD MOTOR COMPANY. Operational energy use and $\mathbf{C O}_{2}$ emissions. 2012. Disponível em: http://corporate.ford.com/microsites/sustainability-report-201112/environment-data-energy. Acesso em: 14 out. 2010.

FUNDAÇÃO GETÚlio VARGAS. GHG Protocol. Metodologia - planilha Excel. 2012. Disponível em: http://www.ghgprotocolbrasil.com.br/index.php?r=site/CapaSecao\&id=1. Acesso em: 10 out. 2012.

GARCIA. J. de S. Perovskitas preparadas pelo método do citrato como catalisadores para reação de redução de NO com CO. 2003. Dissertação (Mestrado em Química) - Instituto de Química de São Carlos, Universidade de São Paulo, São Carlos, 2003. Disponível em: $\quad$ http://www.teses.usp.br/teses/disponiveis/75/75131/tde-25082009-092347/ptbr.php. Acesso em: 03 jan. 2013.

GONZALES, L. M. A. Los impustos amnientales em España. in: TORRES, HELENA TAVEIRA (Org.). Direito tributário ambiental.São Paulo: Malheiros, 2005.

GOUVEIA, N.; FREITAS, C U.; MARTINS, L. C., MARCILIO, I. O. Hospitalizações por causas respiratórias e cardiovasculares associadas à contaminação atmosférica no Município de São Paulo, Brasil. Cadernos de Saúde Pública, Rio de Janeiro, v. 22, n. 2, p. 2669-2677, dez. 2006. http://dx.doi.org/10.1590/S0102-311X2006001200016 
GRUPO BANCO MUNDIAL. International Finance Corporation. Doing Business. Pagamento de impostos. 2012. Disponível em: http://portugues.doingbusiness.org/data/exploretopics/paying-taxes. Acesso em: $31 \mathrm{dez}$. 2012.

HASSAN, A. B. R. da S. Reservas legais e projetos de neutralização de emissões de carbono: uma estratégia para auxiliar a implementação de áreas protegidas na mata atlântica. 2009. 192 f. Dissertação (Mestrado em Planejamento Energético) Universidade Federal do Rio de Janeiro, Rio de Janeiro, 2009.

INSTITUTO BRASILEIRO DE PLANEJAMENTO E TRIBUTAÇÃO - IBPT. Estudo sobre Carga Tributária $\quad \mathbf{X}$ IDH. $2012 . \quad$ Disponível em: http://www.ibpt.com.br/noticia/64/Retorno-de-impostos-no-Brasil-e-pior-que-noUruguai. Acesso em: 30 dez. 2012.

INSTITUTO NACIONAL DE METROLOGIA, QUALIDADE E TECNOLOGIA INMETRO. Programa de etiquetagem veicular. 2013. Disponível em: http://www.inmetro.gov.br/consumidor/pbe/veiculos_leves_2013.pdf. Acesso em: 27 jan. 2013.

INTERGOVERNMETAL PANEL ON CLIMATE CHANGES - IPCC. Changes in atmospheric constituents and in radiative forcing - $4^{\circ}$. Grupo - tabela 2.14. Disponível em: http://www.ipcc.ch/pdf/assessment-report/ar4/wg1/ar4-wg1chapter2.pdf. Acesso em: 30 jan. 2012.

KELSEN, H. Teoria geral do direito e do Estado. São Paulo: Martins Fontes, 2000.

MELO, T. C. C.; CARVALHO, R. N.; SÁ, R. A. B.; CARDOSO, M. J. B. Manutenção e combustível adequados - garantia da durabilidade de emissões. 2009. Disponível em: http://www.aea.org.br/aea2009/downloads/simea09/pap/PAP0070.pdf. Acesso em: 03 jan. 2013.

MENDES JR., L. O jeito é pedalar. Planeta Sustentável. 2008. Disponível em: http://planetasustentavel.abril.com.br/noticia/cidade/conteudo_407301.shtml. Acesso em: 23 out. 2012.

MIE. Prefectural Police Headquarters. Regras básicas para se viver no Japão. 2012. Disponível em: < http://www.police.pref.mie.jp/portugues/>. Acesso em: $30 \mathrm{dez} .2012$.

MILARÉ, É. Direito ambiental: doutrina, prática, jurisprudência e glossário. 2. ed. São Paulo: Revista dos Tribunais, 2001.

NASCIMENTO, L. F. C.; MOREIRA, D. Os poluentes ambientais são fatores de risco para o baixo peso ao nascer? Cadernos de Saúde Pública, Rio de Janeiro, v. 25, n. 8, p. 1791 1796, ago. 2009. http://dx.doi.org/10.1590/S0102-311X2009000800015

NATIONAL GEOGRAPHIC. Mudanças climáticas - mudança no Jogo. São Paulo: Abril, 2012.

NOBRE, C. A.; NOBRE, A. D. O balanço de carbono da Amazônia brasileira. Estudos Avançados, v. 16, n. 45, 2002. http://dx.doi.org/10.1590/S0103-40142002000200006

OBSERVATÓRIO DO CLIMA. Causas da mudança do clima. 2012. Disponível em: http://www.oc.org.br/index.php?page $=$ Conteudo\&id $=5 \& \mathrm{idm}=7 \& \mathrm{mp}=3 \&$ expanddiv $=\mathrm{me}$ nu_1. Acesso em: 10 out. 2012. 
ORGANISATION INTERNATIONALE DES CONSTRUCTEURS D'AUTOMOBILES OICA. Integrated approch. Disponível em: http://oica.net/category/climate-changeand-co2/. Acesso em: 26 maio 2011.

\section{ORGANISATION INTERNATIONALE DES CONSTRUCTEURS D'AUTOMOBILES -} OICA. Production statistics — 2011. Disponível em: http://oica.net/category/production-statistics/. Acesso em: 31 jul. 2011.

OLMO. N. R. S. Poluição atmosférica e exposição humana: a evolução científica epidemiológica e sua correção com o ordenamento jurídico. 2011. Tese (Doutorado em Patologia) - Universidade de São Paulo, São Paulo, 2011. Disponível em: http://www.teses.usp/disponiveis/.../NeideReginaSimoesOlmo.pdf. Acesso em: $31 \mathrm{dez}$. 2012.

ORGANIZAÇÃO DAS NAÇÕES UNIDAS - ONU. El futuro que queremos. 2012. Documento final da Rio+20. Disponível em: https://rio20.un.org/sites/rio20.un.../aconf.216-1-1_spanish.pdf. Acesso em: 10 out. 2012.

PAULSEN, L.; MELO, J. S. de M. Impostos federais, estaduais e municipais. 3. ed. São Paulo: Livraria do Advogado, 2007.

PAVAO, H. G.; NOMURA, D. M. O ozônio da superfície e sua correlação das queimadas. $2009 . \quad$ Disponível em: http://www.propp.ufms.br/gestor/titan.php?target=openFile\&fileId=452. Acesso em: 30 dez. 2012.

PENNA, M. M. de A. P.; REZENDE FILHO, C. de B. Benefícios fiscais a veículos poluidores. Disponível em: http://www.agro.unitau.br:8080/dspace/. Acesso em: 10 out. 2012.

PINTO, K. A. V. S. Introdução ao direito ambiental tributário. Campinas: Alínea, 2012.

SALDIVA, P. H. N.; ANDRADE, M. F.; MIRAGLIA, S. G. E. K.; ANDRÉ, P. A. Etanol e saúde humana: uma abordagem a partir das emissões atmosféricas. 2011. Disponível em: www.unica.com.br/downloads/.../pdf/Matriz_Saúde_Saldiva4.pdf. Acesso em: 05 ago. 2011.

SALIBA, R. B. Fundamentos do direito tributário ambiental. São Paulo: Quartier Latin, 2005.

SÃO PAULO (Estado). Decreto 55.947 de 24 de junho de 2010. Regulamente a Lei $\mathrm{n}^{\circ}$ 13.798, de 9 de novembro de 2009, que dispõe sobre a Política Estadual de Mudanças climáticas. Diário Oficial [do] Estado de São Paulo, Poder Executivo, São Paulo, 21 jan. 2012, Seção I, p. 34.

SÃO PAUlO (Estado). Secretaria do Meio Ambiente - SMA. Política estadual de mudanças climáticas. 2012. Disponível em: http://www.ambiente.sp.gov.br/o-quefazemos/politicas/pemc-politica-es.... Acesso em: 20 nov. 2012.

SINDICATO NACIONAL DA INDÚSTRIA DE COMPONENTES PARA VEÍCULOS AUTOMOTORES - SINDIPEÇAS. Desempenho do setor de autopeças 2012. Disponível em: http://www.sindipecas.org.br. Acesso em: 02 set. 2012.

SMITH, C. B. Análise da difusão de novas tecnologias automotivas em prol da eficiência energética nos veículos leves no Brasil. 2010. 277f. Tese (Doutorado em Planejamento Energético) - Universidade Federal do Rio de Janeiro, Rio de Janeiro, 2010. 
SOCIETY OF MOTOR MANUFACTURERS AND TRADERS - SMMT. Automotive sustainabilit $\mathbf{y}$ report. 13th Edition. 2012. Disponível em: <https://www.smmt.co.uk/reports-publications/\#>. Acesso em: 13 out. 2012.

SOLARI PUENTES, R. S. E. Expansão das florestas plantadas com fins energéticos no Brasil e sua influência nas emissões dos gases de efeito estufa - GEE: análise de dois cenários futuros. 2010. 135f. Dissertação (Mestrado em Planejamento Energético) - Universidade Federal do Rio de Janeiro, 2010.

SOUZA, J. H. de O. Tributação e meio ambiente. Belo Horizonte: Del Rey, 2009.

STREIT, R. Japão recupera 95\% dos componentes de veículos reciclados. Agência CNT de notícias, 15 mar. $2012 . \quad$ Disponível em: http://www.cnt.org.br/Paginas/Agencia_Noticia.aspx?n=8111. Acesso em: 10 out. 2012.

TABOADA, C. P. El Princípio "Quien Contamina Paga” y el Principio de Capacidad Económica in Direito Tributário Ambiental. São Paulo: Malheiros, 2005.

TESOURO NACIONAL (Brasil). Balanço do setor público nacional. 2012. Disponível em: http://www.tesouro.fazenda.gov.br. Acesso em: 31 dez. 2012.

TRIBUNAL DE CONTAS DO ESTADO (São Paulo) - TCE. Relatório de fiscalização de natureza operacional sobre a proposta de um novo Detran. 2011. Disponível em: http://www4.tce.sp.gov.br/sites/default/files/relatorio-detran.pdf. Acesso em: $02 \mathrm{dez}$. 2012.

VELLANI, C. L.; RIBEIRO, M. de S. Sustentabilidade e contabilidade. In: SIMPÓSIO DE ADMINISTRAÇÃO DA PRODUÇÃO, LOGÍSTICA E OPERAÇÕES INTERNACIONAIS - SIMPOI, 9., 2006, São Paulo. Anais eletrônicos... São Paulo: FGV, 2006.

VIANELLO, R. L. Meteorologia básica e aplicações. Viçosa, MG: UFV, 1991.

ZANOBETTI, A.; REDLINE, S.; SCHWARTZ, J.; ROSEN, D.; PATEL, S.; O'CONNOR, G. T. et al. Associations of PM10 with Sleep and Sleep-disordered Breathing in Adults from Seven U.S. Urban Areas. American Journal of Respiratory and Critical Care Medicine, v. 182, n. 16, p. 819-825, 2010. http://dx.doi.org/10.1164\%2Frccm.20091217970C 